\title{
PHYLOGENETIC ANALYSIS OF PROTOZOA AND SISTAN COW'S RUMEN BACTERIA FED WITH FORAGE RATIONS BY MOLECULAR AND LABORATORY METHODS
}

(Análise filogenética de bactérias de rúmen de protozoários e de Sistan Cow alimentadas com rações de forragem por métodos moleculares e laboratoriais)

Gholam Pishkar ${ }^{1}$, Mohamamd Reza Dehghani $^{1}$, Sajjad Sarikhan ${ }^{2}$, Mostafa Yosf Elahi ${ }^{1}$

\begin{abstract}
${ }^{1}$ Department of Animal Seience, Faculty of Agriculture, University of Zabol, Zabol, Islamic Republic of Iran; ${ }^{2}$ Scientific Member in Molecular Bank, Iranian Biological Resource Center (IBRC), ACECR,

Tehran, Islamic Republic of Iran
\end{abstract}

\section{Corresponding author: mohrezadehghani@yahoo.com}

\begin{abstract}
The present study was conducted to investigate the properties of rumen Microbiome in Sistani cattle by performing molecular experiments to clone the 18S rRNA genes of protozoans, culture rumen bacteria and then sequencing their 16S rRNA gene. Rumen liquid samples were collected from 10 Sistani cattle from the Sistan region, which were kept in a similar feeding group and fed on forage rations, through stomach tubes before feeding in the morning. The protozoa genome was extracted by the ASL buffer of the QiaAmp DNA stool kit (Qiagen), and their $18 S$ rRNA gene was amplified and isolated with specific primers by the PCR method. The quantity and quality of DNA extracted with nanodrop 1000 and electrophoresis on 1\% agarose gel, respectively, have been in The 18S rRNA protozoan gene was cloned using the T/A cloning technique in the PTZ plasmid and then the recombinant plasmid was transferred to $\mathrm{E}$. coli.vestigated. The bacteria were cultured with the dependent method and then their 16S rRNA gene was sequenced. Rumen bacteria culture was performed in an anaerobic culture medium using an anaerobic chamber with flexible plastic gloves. After purification, the bacteria were partially studied morphologically. Then the bacterial genome was extracted using a kit, and the 16S rRNA gene was propagated by PCR methods. The sequences have been sent to determine the final structure of the gene for sequencing. In the end, the phylogenetic tree is drawn using the MEGAX software.Investigating of the microbial sequences obtained from the rumen of the cattle showed that the results are somewhat consistent with the results of other researchers in other countries and in other animals, but in some cases, there are significant differences. In this study, the Entodinium genus was the dominant protozoan group in the Sistani cattle's rumen. In the library, OTUs had a similarity of over $98.5 \%$ with the protozoan sequences identified in the database. The results of the culture of bacteria showed Ruminococcus albus, Ruminococcus flavefaciense, Clostridium colinum, Streptococcus equinus and butyrivibrio genus, which had a high similarity of $96.54 \%$ with the bacterial sequences identified in the database. Ruminal microbial ecology is very complex. The real scope of this diversity is determined by the use of molecular identification methods for species. The complexity of this diversity is determined by the use of 16S rRNA genes and 18S rRNA genes. Since each microbial species occupies a small area and is found only in some animals.
\end{abstract}

Keywords: $16 \mathrm{~S}$ rRNA, 18S rRNA; bacteria; protozoa; phylogeny; rumen; Sistani cattle. 
RESUMO: presente estudo foi conduzido para investigar as propriedades do microbioma ruminal em bovinos Sistani realizando experimentos moleculares para clonar os genes 18S rRNA de protozoários, cultivar bactérias do rúmen e então sequenciar o gene 16S rRNA. Amostras líquidas de rúmen foram coletadas de 10 bovinos Sistani da região de Sistan, que foram mantidos em um grupo de alimentação semelhante e alimentados com rações forrageiras, através de tubos estomacais antes da alimentação pela manhã. O genoma dos protozoários foi extraído pelo tampão ASL do kit de fezes QiaAmp DNA (Qiagen), e seu gene 18S rRNA foi amplificado e isolado com primers específicos pelo método de PCR. A quantidade e qualidade do DNA extraído com nanodrop 1000 e eletroforese em gel de agarose a $1 \%$, respectivamente, foram clonadas no gene do protozoário $18 \mathrm{~S}$ rRNA usando a técnica de clonagem T / A no plasmídeo PTZ e então o plasmídeo recombinante foi transferido para $\mathrm{E}$ coli.vestigado. As bactérias foram cultivadas com o método dependente e então o gene $16 \mathrm{~S}$ rRNA foi seqüenciado. A cultura de bactérias do rúmen foi realizada em meio de cultura anaeróbico usando uma câmara anaeróbica com luvas plásticas flexíveis. Após a purificação, as bactérias foram parcialmente estudadas morfologicamente. Em seguida, o genoma bacteriano foi extraído usando um kit, e o gene 16S rRNA foi propagado por métodos de PCR. As seqüências foram enviadas para determinar a estrutura final do gene para o sequenciamento. No final, a árvore filogenética é desenhada usando o software MEGAX. A investigação das seqüências microbianas obtidas no rúmen do gado mostrou que os resultados são um pouco consistentes com os resultados de outros pesquisadores em outros países e em outros animais, mas em alguns casos, existem diferenças significativas. Neste estudo, o gênero Entodinium foi o grupo protozoário dominante no rúmen do gado Sistani. Na biblioteca, as OTUs tiveram uma similaridade de mais de $98,5 \%$ com as sequências de protozoários identificadas no banco de dados. Os resultados da cultura de bactérias mostraram Ruminococcus albus, Ruminococcus flavefaciense, Clostridium colinum, Streptococcus equinus e butyrivibrio, que apresentaram alta similaridade de $96,54 \%$ com as seqüências bacterianas identificadas no banco de dados. A ecologia microbiana ruminal é muito complexa. O alcance real dessa diversidade é determinado pelo uso de métodos de identificação molecular para espécies. A complexidade dessa diversidade é determinada pelo uso de genes 16S rRNA e genes $18 \mathrm{~S}$ rRNA. Já que cada espécie microbiana ocupa uma área pequena e é encontrada apenas em alguns animais.

Palavras-chave: bactérias; filogenia; gado Sistani; protozoários, rúmen, rRNA 16S, rRNA 18S. 


\section{INTRODUCTION}

Ruminants are considered to be domesticated grassland animals, which make the most significant contribution to the conversion of unusable human herbs into useful food products and providing food and human health. These animals provide $70 \%$ of the usable animal proteins and $10 \%$ of the natural fibers used by humans. The most prominent part of the ruminant feed is the wall of plant cells, while these animals cannot produce necessary enzymes for the decomposition of cellulose and hemicellulose, which are the main component of these fibers. For this reason, they rely on the fermentation of these compounds by microorganisms based on the rumen to obtain and use the cell walls of the plant (Hanafy et al, 2017).

In the rumen, cellulose and lignocellulosic material digestion are performed by a complex set of microorganisms. Per each $\mathrm{mL}$ of rumen liquids more than $10^{10}$ to $10^{11}$, bacterial cells are observed (Qi et al., 2010). Ruminal cellulose Parser bacteria convert carbohydrate polymers into sugar units by binding to lignocellulosic material and secreting glycoside hydrolysis enzymes. The main bacteria are the rumen cellulose Parser or belonging to the gram-negative group of Fibrobacter succinogenes or the two Gram-positive species of Ruminococcus flavefaciens or Ruminococcus albus (Krause et al., 2003).

Butyrivibri fibrisolvent strains are positive gram-positive bacteria that play a crucial role in xylose digestion, the components of the Hemicellulose content in the cell wall of plants. Prevotella bacteria, although they produce a range of xylosidase enzymes, are not considered to be cellulose Parser species. Some cellulose Parser species, such as cellulosolvens Eubacterium, are not well identified, and there is little information about them (Nagaraja et al., 2016).
The ruminal microbial population of the cattle is not always constant and the density of different groups of ruminal microorganisms has always been influenced by several factors such as livestock age, feeding behavior, production level, animal health, nature and relationships between different microbial populations as well as external factors such as the chemical composition of the diet Nutrition, the nature of the diet, seasonal variation, changes throughout the day, geographical factors, etc.(Wang et al., 2017).

There have been significant differences in the number and types of microbial species available in Ruminants rumen due to the genetic and environmental differences that affect the ability of digestion and fermentation of consuming food by animals (Roehe et al., 2016). Today, the criterion for the classification of bacteria is based on polyphasic taxonomy, which its principle, based on genetic studies, DNA-DNA hybridization, chemotaxonomy, and phenotypic (Jami \& Mizrahi, 2012).

The first bacterial genetic studies directly based on rRNA and the ability of the reverse transcriptase enzyme to polymerize the bases from an RNA template. Microbiologists have sequenced rDNA genes. Since rDNA genes are highly protected, it is possible to design a specific primer for them (Wright \& Baum, 2018). PCR methods have identified small rhizome RNA subunits and intergenic spacers of several protozoan rhizomes morphologically (Karnati et al., 2003).

Ciliate protozoa are known as a microbial population residing in the gastrointestinal tract of a wide range of ruminants and non-ruminating herbivores. In the rumen ecosystem of these animals, Ciliate can produce up to $50 \%$ of total microbial nitrogen and have a density of $10^{5}$ to $10^{6}$ cells per $\mathrm{ml}$ of ruminal liquid. Although Ciliates are not 
essential for digestion and host survival, they contribute to overall intestines function. For example, by increasing the destructive complexity of digestion, the ability to eliminate oxygen or through animal grazing behaviors helps to form and shape the prokaryotic rumen populations (Kittelmann et al., 2015).

Protozoa Species and population of the rumen are based on the host's nutritional requirements, diet composition, physiological factors, and daily variability. The morphological classification of protozoan species and known effects on bacterial population and host nutrition has been discussed so far, but many of these studies have been based on microscopic studies. Although rumen protozoans help to parse food fibers and reduce the rate of fermentation by absorbing starch grains, they are probably the main antagonists for efficient use of protein in the rumen microbial environment (Leng et al., 2011).

Sistani cattle a Bos indicus breed exist as a black, black and white parti-color, semi-wild-heavyweight- with a large and strong bulk that has special genetic features that have been adapted to nonfertile areas. That's why over the past few years, it's important to use this biotype in the meat industry. The breeding system of these castles has not been controlled and no selective criteria have been used to improve this breed. Another distinctive feature of Sistani's cattle is its excellent ability to withstand many diseases, which makes this native breed a potential candidate for future breeding (Gorji et al., 2017).

This important genetic source (the genetic mass of Sistan's native cattle) has been threatened with extinction despite its considerable resistance to pathogenic and environmental perturbations, due to climate change and poorly managed breeding. Sistani cattle are classified in the category of broiler cattle and are capable of accepting more heat than commercial races against high environmental temperatures that can be used in artificial insemination and embryo transfer programs, especially in the desert and tropical regions (Faraji et al., 2019).

Some of the literature on the subject discussed in this paper is as follows:

Kittelmann et al. (2015) investigated the phylogeny of Intestinal Ciliate, including Charonina ventriculi, and compared microscopy and sequencing of the $18 \mathrm{~S}$ rRNA gene to analyze the structure of ruminal Ciliate populations. The results of their study showed that the microscopic method is a very precise method for evaluating the total number or relative frequency of the different species of ciliate is a sample. While the sequencing of the $18 \mathrm{~S}$ rRNA gene showed that this method could be an invaluable Proposal to compare the stingray population structure in a larger number of samples from different animals or Studied groups. Leng et al. (2011) evaluated the Yunnan Yellow cattle's rumen protozoa based on the $18 \mathrm{~S}$ rRNA sequence. Their results showed that the use of molecular techniques could be useful for assessing diversity, population dynamics, community composition, and rumen protozoan diversity.

A study by Han and et al in 2015 using sequencing of $16 \mathrm{~S}$ rRNA gene on goats of different ages, Showed that in 80-day-old goats, Frimicute (41.1\%) Synergistete $(36.76 \%)$, Bacteroidetes $(19.70 \%)$ were dominant phylumes, which changed the population distribution trend by increasing the age per 10 days, and Eventually, at 110 days of age, Bacteroidetes with $63.96 \%$, Firmicutes with $17.92 \%$, Proteobacteria with $8.05 \%$, and Synergistetes with $7.5 \%$ of dominant phylumes in the rumen of goats. In a study conducted on Surti 
goats in India, it was also reported that in these animals, that were fed with a mixture of concentrates and forage, $35 \%$ of the clones belonged to the Bacteroidete phylum and $33.33 \%$ belonged to the Firmicute phylum (Patel et al. 13, 2011). PCR-based techniques, along with cloning and sequencing analysis, can provide more information on protozoa and rumen bacteria, since there is no need for the ability to culture microorganisms in this method. The aim of this study was to investigate the phylogenetic diversity of protozoan populations of ruminal liquid samples by cloning $18 \mathrm{~S}$ rRNA and also phylogenetic analysis of its bacterial population using a 16S rRNA-dependent cultivation and sequencing method in Sistani cattle in Sistan region of Iran.

\section{MATERIALS AND METHODS}

\section{Livestock specimens and food rations}

Ten Sistani cattle from Zabol, who were fed with forage diets, were selected. Their rumen samples were collected before the morning feed. Rumen liquid samples were prepared through a stomach tube with a bending ability and a diameter appropriate to the size of the livestock. This livestock was female and physically healthy and free from any disease, and their ages ranged from 3.5 to 5 . The forage used by the specimens in this study was alfalfa hay (ALF), Phragmites australis (PA) and wheat straw (WS). In order to adapt and adopt ruminal microorganisms to diets, experimental animals were fed twice to 8:00 am and 16:00 pm at the maintenance level (livestock).

\section{The Sampling of rumen contents}

Sampling was done sterilized. Rumen liquid samples were collected in $50 \mathrm{ml}$ falcons that were pre-autoclaved and numbered. Then, they were placed inside plastic nylon and then in a flask containing nylon water at a temperature of $42^{\circ} \mathrm{C}$. The silicon was applied to the door, preventing oxygen from penetrating it. Liquid specimens were identified by numbers $L_{1}, L_{2}, \ldots$, and $L_{10}$. The samples were transferred to the lab by air transportation as expeditiously as possible and were quarantined under anaerobic conditions. Finally, 10 samples of Sistani cattle's Rumen liquid were collected. The fluid samples were strained through four layers of cheesecloth under anaerobic conditions to provide Clarified Rumen liquid (CRF).

\section{Counting protozoans in rumen liquid}

After collecting and transferring fresh rumen liquid to the laboratory, from each sample, a smaller sample was prepared in a volume of $5 \mathrm{ml}$. To confirm the protozoa, a $10 \%$ formaldehyde fixative solution and $9 \%$ sodium chloride solution were used. One $\mathrm{ml}$ of ruminal fluid was added to one fixed droplet of solution. After protozoa fixation, put one drop of rumen fluid on a special grading slide from each tube and, after inserting the lamell on it, the monoclonal cells underneath the microscope at a magnification of $\times 10$, the quadrilateral cells were counted in the middle of the lam (Dehority et al., 1984).

Isolating of germs from rumen liquid samples and DNA extraction

In order to isolate and collect the microbes in the liquid phase, under anaerobic conditions, a centrifuge process was carried out at a gravity acceleration of $500(500 \mathrm{xg})$ and a temperature of $4^{\circ} \mathrm{C}$ on liquids collected from the rumen to remove the solids residues. Then 20-30 milliliters of the liquid phase in another falcon was subjected to centrifugation with a gravity acceleration of $12,000 \mathrm{xg}$ for 10 minutes to precipitate the microbial cells. Cell sediment was then dissolved in a $1.4 \mathrm{ml}$ ASL buffer of the DNA extraction kit (QiaAmp DNA stool mini kit). The extraction of microbial DNA using the kit was based on DNA extraction protocol 
from feces to detect pathogens. The quantitative examination of the extracted DNA was carried out using a spectrometer or Nanodrop 1000 spectrometer (Hernandez et al., 2019). The extracted DNA quality was also carried out using the horizontal electrophoresis on the agarose gel. First, an agarose gel $1 \%$ was prepared. For providing agarose gel $1 \%, 0.1 \mathrm{~g}$ of agarose was poured into Arlen and then $100 \mathrm{ml}$ of TAE buffer was added (Senés et al., 2019). Gel staining was done with Ethidium bromide solution (Saki et al.,
2016). It should be noted that some of the rumen liquid was transferred to the synthetic culture media for bacterial culture before DNA was extracted from the rumen liquid samples.

\section{Primers used to PCR of protozoa}

The 18S rRNA protozoan gene was amplified and isolated by specific primers by PCR Method (Leng et al., 2011). The primers used to propagate the 18SrRNA gene for protozoa are shown in Table 1.

Table 1 - The primers used for the amplicon of 18SrRNA gene.

\begin{tabular}{ccc}
\hline Primer name & Orientations & Sequence \\
\hline P-SSU-342f & Forward & $5^{\prime}$-CTTTCGATGGTAGATTGGAC-3' \\
Medlin B & Revers & $5^{\prime}$-CTTGTTACGACTTCTCCTTCC-3' \\
\hline
\end{tabular}

Protozoans polymerase chain reaction

At this step for synthesis mixed solution of PCR buffer with a concentration of $10 \mathrm{X}$ plus 1 unit of enzyme and $50 \mu \mathrm{l}$ of $\mathrm{MgCl}_{2}$ at a concentration of $50 \mathrm{mM}$ and $25 \mu \mathrm{l}$ of dNTP at $10 \mathrm{mM}$ concentrations was mixed with $800 \mu$ l of injected water in a volume of $1000 \mu \mathrm{l}$. Also, $1 \mu \mathrm{l}$ of Diluted Taq polymerase (1.25 units of enzymecontaining $0.25 \mu \mathrm{l} 5 \mathrm{u} / \mu \mathrm{l}$ Taq polymerase enzyme at a concentration of $5 \mu \mathrm{g} / \mu \mathrm{l}$ plus $0.75 \mu \mathrm{l}$ of distilled water) in a $0.2 \mathrm{ml}$ microtube, was used. Table 2 shows the components of the polymerase chain reaction with the volume of each component used for a $25 \mu$ volume reaction.

Table 2- the volume of the components of the PCR reaction of the protozoa

\begin{tabular}{cc}
\hline Components of the PCR reaction & volume \\
\hline Mixed solution(Including & $20 \mathrm{Ml}$ \\
MgCl2,dNT,Water) & \\
Forward primer & $1 \mathrm{Ml}$ \\
Reverse primer & $1 \mathrm{Ml}$ \\
Taq enzyme & $1 \mathrm{Ml}$ \\
Protozoan DNA & $2 \mathrm{Ml}$ \\
Total & $25 \mathrm{Ml}$ \\
\hline
\end{tabular}

The PCR temperature program was carried out in three stages, the first and second stages of which included three parts. The temperature schedule for the various stages of the PCR cycle is presented in Table 4. The best reaction program and the production of the best PCR product, the optimum value of DNA and optimal binding temperature for the $25 \mu$ reaction volume were obtained after several times of testing and repetition.

Table 3- the PCR Temperature Program

\begin{tabular}{|c|c|c|}
\hline Stage & Temperature & Time \\
\hline \multirow{3}{*}{ First (10 cycles) } & $94 \circ \mathrm{C}$ & $40 s$ \\
\hline & $55 \circ C$ & $40 s$ \\
\hline & $72 \circ C$ & $2 \min$ \\
\hline \multirow{3}{*}{$\begin{array}{l}\text { Second (20 } \\
\text { cycles) }\end{array}$} & $92 \circ C$ & $30 \mathrm{~s}$ \\
\hline & $55^{\circ} \mathrm{C}$ & $40 s$ \\
\hline & $72 \circ \mathrm{C}$ & $2.5 \mathrm{~min}$ \\
\hline Third & $72 \cdot \mathrm{C}$ & $6 \min$ \\
\hline
\end{tabular}

Plasmid and bacteria used to clon the $18 \mathrm{~S}$ rRNA protozoan genes

The gene was cloned using the T/A cloning technique in the PTZ57R/T plasmid (abbreviated as PTZ) and then entered into $E$. coli bacteria according to the standard protocol (Kumar et al., 2019). Plasmid extraction from E. coli was performed using a plasmid 
extraction kit (Sinoclon, Iran). This plasmid contains 2886 pair of the base. according to the manufacturer's instructions, The purified PCR products were entered into PTZ plasmid and transformed to DHa E.coli cells with calcium chloride $(0.1 \mathrm{M})$, using T/A kit (sinaclon, Iran), The recombinant plasmids were extracted and sent using a plasmid extraction kit (sinaclon, Iran) for sequencing. In this study, E. coli DHa cells were used as cloning hosts, cultured in Luria Bertani (LB) medium containing ampicillin antibiotic $(50 \mu \mathrm{g} \mathrm{ml}$ 1) (Shin et al 2004). The synthesis method of this culture is presented in Table 4.

Table 4- Luria Bertani liquid culture medium, $\mathrm{pH}$ medium, was adjusted to 7.5 and the cells were cultured at $37^{\circ} \mathrm{C}$ aerobically.

\begin{tabular}{cc}
\hline Material & amount \\
\hline tryptone & $1 \%$ \\
Yeast extract & $0.5 \%$ \\
Sodium Chloride & $0.5 \%$ \\
Ampicillin & $100 \mu \mathrm{g} / \mathrm{ml}$ \\
\hline
\end{tabular}

Method of culture and counting of ruminal liquid sample bacteria

Isolation was performed using conventional serial dilutions and successive tubes of selective enriched microbial cultures for rumen bacteria.
Severe anaerobic conditions were applied at all stages of isolation. In this study, Das and Kane were used for the culture of bacteria (Das \& Qin, 2012).

Table 5- Materials needed to synthesize the culture medium used by Das and Qin.

\begin{tabular}{|c|c|}
\hline Material & Amount \\
\hline $\begin{array}{c}\text { Mineral solution } 1\left(3 \mathrm{~g} / \mathrm{L} \mathrm{KH}_{2} \mathrm{PO}_{4}, 6 \mathrm{~g} / \mathrm{L}\left(\mathrm{NH}_{4}\right)_{2} \mathrm{SO}_{4}, 0.8 \mathrm{~g} / \mathrm{L} \mathrm{CaCl}_{2} .2 \mathrm{H}_{2} \mathrm{O}, 0.6\right. \\
\left.\mathrm{g} / \mathrm{L} \mathrm{MgSO} \mathrm{Mg}_{4} \text { and } 6 \mathrm{~g} / \mathrm{L} \mathrm{NaCl}\right)\end{array}$ & $15 \mathrm{~mL}$ \\
\hline Mineral solution $2\left(3 \mathrm{~g} / \mathrm{L} \mathrm{K}_{2} \mathrm{HPO}_{4}\right)$ & $15 \mathrm{~mL}$ \\
\hline Resazurin $0.1 \%$ & $0.3 \mathrm{~mL}$ \\
\hline Distilled water & $50 \mathrm{~mL}$ \\
\hline Sodium carbonate & $0.4 \mathrm{~g}$ \\
\hline Cysteine chloride & $50 \mathrm{~mL}$ \\
\hline Smooth rumen liquid & $20 \mathrm{ml}$ \\
\hline Hemin $(0.05 \%)$ & $0.2 \mathrm{ml}$ \\
\hline Yeast extract & $0.25 \mathrm{~g}$ \\
\hline triotone & $1 \mathrm{~g}$ \\
\hline cellobiose & $0.1 \mathrm{~g}$ \\
\hline Microcrystalin cellulose & $0.5 \mathrm{~g}$ \\
\hline
\end{tabular}

After incubation, two different criteria, culture medium, color change (clouding) with eye observation and $\mathrm{pH}$ reduction were used to determine the growth status of bacteria in each tube. Then, using the MPN table, the number of bacteria per $\mathrm{ml}$ of rumen liquid was estimated.

Molecular identification of bacteria using 16S rRNA sequence
The DNA of bacteria cultured was extracted using a DNA extraction kit from bacteria. (Gene Transfer Pioneers or GTP Company)To reproduce a fragment of the 16S rRNA gene that was suitable for sequencing, a degenerate primer pair was used (Table 6). These primer pairs propagate a 464 pairing piece of variable regions V3-V4 of the 16S rRNA gene. Previous studies have shown that this primer pair works very 
well for the classification of bacteria in the Phylum and Domain (Klindworth et al., 2013). The primers used to reproduce the 16SrRNA gene of bacteria are also given in Table 6 (Kim et al., 2017).

Table 6- primers used to propagation 16SrRNA bacteria

\begin{tabular}{ccc}
\hline Primer name & orientations & Sequence \\
\hline S-D-Bact-0341-b-S-17 & Forward & $5^{\prime}$-CCTACGGGNGGCWGCAG-3' \\
S-D-Bact-0785-a-A-21 & Revers & $5^{\prime}$-GACTACHVGGGTATCTAATCC-3' \\
\hline
\end{tabular}

The PCR conditions were $94^{\circ} \mathrm{C}$ for 4 minutes, 30 cycles $94^{\circ} \mathrm{C}$ for 30 seconds, $55^{\circ} \mathrm{C}$ for 40 seconds, $72^{\circ} \mathrm{C}$ for 1 minute, and $72^{\circ} \mathrm{C}$ for 7 minutes at the final stage (Gharechahi et al., 2015). The PCR product was finally sent for nucleotide sequencing.

Drawing phylogenic tree for bacteria and protozoa

All reference sequences were obtained from Gene Bank and the Ribisimal Database Project (RDP). Sequences obtained by the CHECKCHIMERA program were analyzed to eliminate any unreal rRNA gene clones. The similarity was found with the information on the database using the BLAST online search (Kittelmann et al., 2015) and the most similar sequences were selected as a reference in the phylogenic tree. Balancing the sequences by CLUSTAL W Multiple Sequence Balance was done in Mega Software. The phylogenetic tree for bacteria and protozoans with using the Neighbor-joining (NG) method and with the help of MEGAX (Molecular Evolutionary Genetics Analysis) software was drawn to describe kinship relationships (Ringo et al., 2018). The tree was evaluated using a Bootstrap test based on 1000 sampling replicates.

\section{RESULTS}

Analysis of $18 S$ rRNA clone library sequences of the protozoa
27 clones from the ruminal fluid library were under the sequence matching searches using GenBank, which runs the BLAST algorithm, and the RDP database running the SIMILARITY-RANK program. The high coverage showed that the library was well sampled. The similarity of the cloned sequences to the $18 \mathrm{~S}$ rDNA sequences of the identified protozoa in the databases varied from $98.5 \%$ to $99.96 \%$ percent. In Table 1, the similarity of $18 \mathrm{~S}$ rRNA sequences extracted from rumen fluid is presented. These sequences were divided into two significant morphotypes: Entodiniomorphida and Vestibuluferida.

Phylogenetic analysis of 185 rRNA sequences of protozoans

Since the similarity values for most of our sequences were less than those that could be attributed to a particular class with a reasonable degree of certainty, the phylogenic analysis was performed to determine the position of their classification. The phylogenetic analysis of the sequences derived from the Sistani cattle rumen liquid Library (SCRLP designated for the Sistani cattle rumen liquid protozoa) is shown in Fig. 1. As indicated in the figure, the phylogenetic tree of the 18S rRNA gene of the rumen protozoa is divided into four major clusters.

In this library, about $92 \%$ of the sequences were placed in the Entodiniomorphidae and $8 \%$ in the Vestibuluferidae order as phylogenetic. 
Table 7- the similarity of $18 \mathrm{~S}$ rRNA sequences extracted from rumen liquids

\begin{tabular}{cccc}
\hline Clone & Genera & Nearest relative & Similarity\% \\
\hline SCRLP1 & Entodinium & Entodinium longynucleatum & $99.80 \%$ \\
SCRLP2 & Entodinium & Entodinium longynucleatum & $99.80 \%$ \\
SCRLP3 & Entodinium & Entodinium bursa & $99.80 \%$ \\
SCRLP4 & Entodinium & Entodinium bursa & $99.67 \%$ \\
SCRLP5 & Entodinium & Entodinium bursa & $98.50 \%$ \\
SCRLP6 & Entodinium & Enntodinium dubardi & $99.80 \%$ \\
SCRLP7 & Entodinium & Enntodinium dubardi & $99.74 \%$ \\
SCRLP8 & Entodinium & Enntodinium dubardi & $99.74 \%$ \\
SCRLP9 & Entodinium & Enntodinium dubardi & $99.74 \%$ \\
SCRLP10 & Entodinium & Enntodinium dubardi & $99.67 \%$ \\
SCRLP11 & Entodinium & Enntodinium dubardi & $99.67 \%$ \\
SCRLP12 & Entodinium & Entodinium caudatum & $98.96 \%$ \\
SCRLP13 & Entodinium & Entodinium caudatum & $98.90 \%$ \\
SCRLP14 & Entodinium & Entodinium caudatum & $98.84 \%$ \\
SCRLP15 & Entodinium & Entodinium caudatum & $98.60 \%$ \\
SCRLP16 & Entodinium & Entodinium caudatum & $99.00 \%$ \\
SCRLP17 & Entodinium & Eudiplodinium maggii & $99.76 \%$ \\
SCRLP18 & Eudiplodinium & Eudiplodinium maggii & $99.69 \%$ \\
SCRLP19 & Epidinium & Epidinium caudatum & $99.76 \%$ \\
SCRLP20 & Epidinium & Epidinium caudatum & $99.93 \%$ \\
SCRLP21 & Polyplastron & Polyplastron multivesiculatum & $99.57 \%$ \\
SCRLP22 & Polyplastron & Polyplastron multivesiculatum & $99.54 \%$ \\
SCRLP23 & Polyplastron & Polyplastron multivesiculatum & $99.48 \%$ \\
SCRLP24 & Polyplastron & Uncultured rumen protozoa & $99.87 \%$ \\
SCRLP25 & Polyplastron & Uncultured rumen protozoa & $99.80 \%$ \\
SCRLP26 & Dasytricha & Dasytricha ruminantum & $99.08 \%$ \\
SCRLP27 & Dasytricha & Dasytricha ruminantum & $99.67 \%$ \\
\hline & & &
\end{tabular}

In the library, 3 sequences (SCRLP21, SCRLP22, and SCRLP23) to Polyplastron multivesiculatum, 2 sequences (SCRLP24 and SCRLP25) were not cultured to rumen protozoa, and 2 sequences (ACRL517 and SCRLP18) to Eudiplodinium maggii, 2 sequences (SCRLP19 and SCRLP20) to Epidinium caudatum, 2 sequences (SCRLP1 and SCRLP2) to Entodinium longynucleatum, 2 sequences (SCRLP26 and SCRLP27) to Dasytricha ruminantum, 6 sequences (SCRLP6, SCRLP7, SCRLP8, SCRLP9, SCRLP7 and SCRLP11) to Enntodinium dubardi, 3 sequences (SCRLP3, SCRLP4 And SCRLP5) belonged to Entodinium bursa, 5 sequences (SCRLP12, SCRLP13, SCRLP14, SCRLP15 and SCRLP16) to
Entodinium caudatum and 2 sequences (SCRLP24 and SCRLP25) to Uncultured rumen protozoa. Two clones belonging to the not cultured rumen protozoa were related to the Polyplastron genus. In the studied library, no sequences related to Entodinium nanellum, Isitricha intestinalis, Ophryoscolex purkynjei, and Diplodinium dentatum were found.

The results in this study showed that Entodinium was the dominant group in the Sistani cattle's rumen. In our case study library, OTUs had a $98.9 \%$ similarity to the ciliate protozoan sequences identified in the database, which suggests that the sequences are roughly identical to those of the rumen identified sequences in the databases. In this library, also, 2 OTUs are similar to 
non-cultivated rumen protozoa that can be susceptible to new species. However, it is difficult to conclude that these OTUs belong to new species or not.

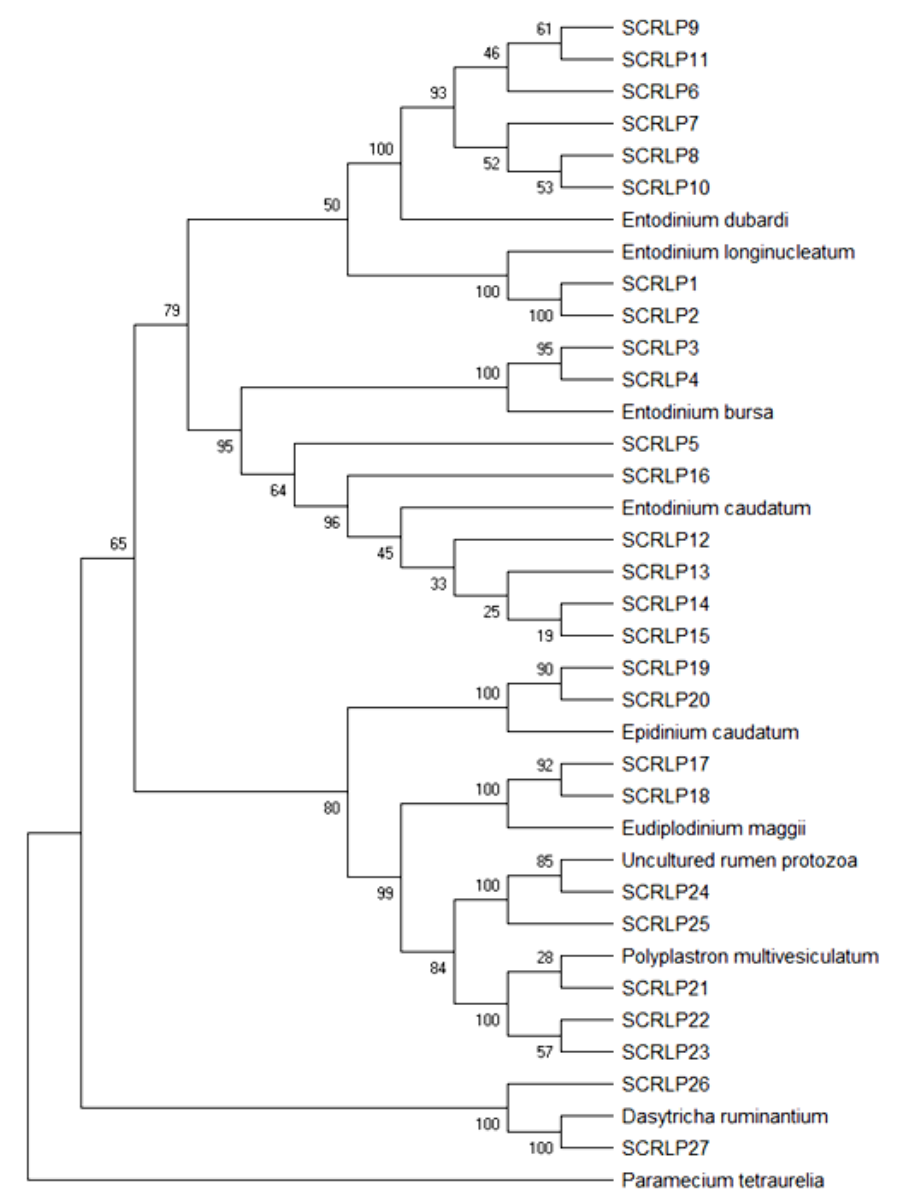

Fig 1 - The phylogenetic tree Sistani cattle rumen liquid protozoa (SCRLP) fed forage diets was constructed using MEGAX software, from Paramecium tetraurelia was used as an outgroup for rooting the tree.

Phylogenetic analysis of $16 S$ rRNA sequences of bacteria

A total of 18 clones of the $16 \mathrm{~S}$ rRNA gene related to bacteria from the contents of the rumen fluid of Sistani cattle were analyzed. Then they searched for the rate of their compatibility with databases including gene bank and ribosomal database project. In this study, 5 sequences (27.77\% of the total library clones) comprise clones of SCRLB1, SCRLB2, SCRLB3, SCRLB4 and SCRLB5 clones have the similarity of $97.87 \%$ to $99.87 \%$ with Ruminicoccus albus, 5 sequences
(27.77\% of clones) comprise clones of SCRLB6, SCRLB7, SCRLB8, SCRLB9 and SCRLB10 clones have the similarity of $97.95 \%$ to $99.5 \%$ with Ruminicoccus flavefaciense, 3 sequences $(16.66 \%$ of the clones) comprise the clones of SCRLB11, SCRLB12 and SCRLB13 clones have the similarity of $97.75 \%$ to $99.58 \%$ with species of butyrivibrio, 3 sequences of $(16.66 \%$ of clones) comprise the clones of SCRLB14, SCRLB15 and SCRLB16 clones have the similarity of 96.65 to $99.59 \%$ with Clostridium colinum and 2 sequences of (11.11\% of Clones) comprise SCRLB17 
and SCRLB18 clones have the similarity of 98.87 to $99.94 \%$ with Streptococcus equinus.

\section{Phylogenetic Analysis of the 16S rRNA} Clone library of Bacteria

Phylogenetic analysis obtained from the sequences derived from the gene clogen16S rRNA cluster of Sistani cattle shows that $100 \%$ of the isolated clones in this study belong to the Firmicutes phylum. Namely, clones that are similar to Ruminicoccus albus, Ruminicoccus flavefaciense, Clostridium colinum, Streptococcus equinus, and species of butyrivibrio are in the Firmicutes phylum.

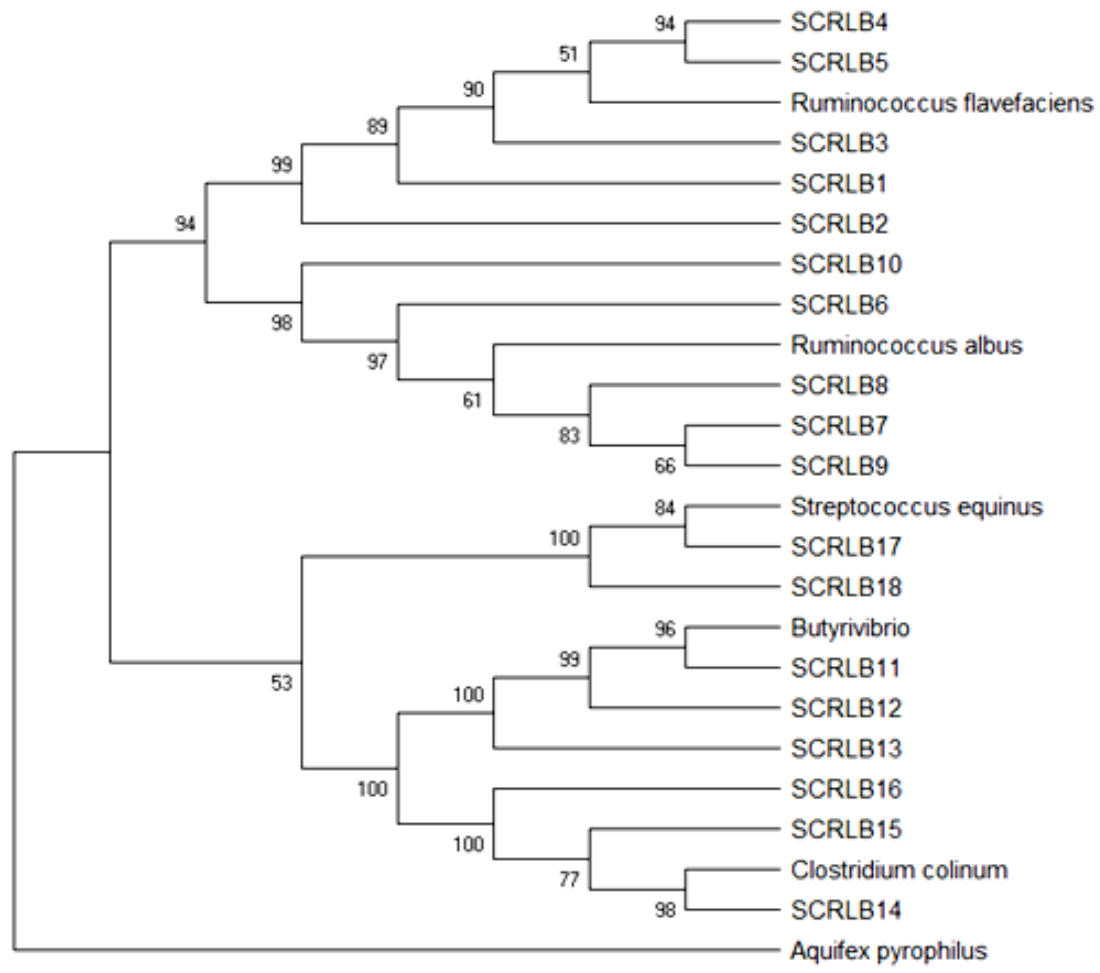

Figure 2 - The phylogenetic tree of the Sistani cattle rumen liquid bacteria (SCRLB) fed forage diets was constructed using MEGAX software. Aquifex pyrophilus was used as an outgroup for rooting the tree.

\section{DISCUSSION}

\section{Rumen Protozoa}

Compared to rumen bacteria and fungi, the information available on rumen protozoa is still relatively limited. The relative lack of information available on rumen protozoa can be due to problems of isolation, culture, or maintenance. Rumen isolates loose livability due to unknown reasons during propagation or under the culture of pure isolates. Also, the use of classical morphological criteria, the amount of DNA extracted may provide little some species for propagation, and there may also be impurities in the DNA extracted. Enrichment of PCR and improver primers can lead to the identification of the true diversity and variety of rumen protozoa composition (Lang et al., 2010). More than 42 species of rumen protozoa have been described based on culture and morphological studies (Dehoriti, 2018). Although only a few sequences of a limited number of protozoa is available in the databases, this generally indicates the well-known 
species dominant in the rumen. Eleven species of protozoa represent the populations of these unicellular in the rumen of the cattle: Entodinium, Diplodinium, Eudiplodinium, Ostracodinium, Metadinium, Enoploplastron, Polyplastron, Epidinium, Ophryoscolex, Isitricha and Dasytricha (Karnati et al. 2003). Compared to other ecosystems, they have studied microscopic protozoa in the rumen of cattle. In the last decade, a rapid method for the identification of rumen protozoa in the rumen has been created without the need for culture (Kernati et al., 2003; Shin et al., 2004). For the first time, this research investigated the molecular diversity of protozoa in rumen of Sistani cattle using cloning of the $18 \mathrm{~S}$ rRNA gene.

The results obtained of this research are similar to those of previous studies, but in some cases, there are significant differences. Abrar and his colleagues in 2016, researching the variation and fluctuation of the population of the cilium protozoa in the rumen of the cattle, showed that more than $80 \%$ of the sequences were phylogenetic in the species of Entodinium. The other sequences were Diploplastron (5\%), Dasytricha (8.3\%) and Isotricha $(3.3 \%)$. Our results also showed that Entodinium is the dominant species of rumen protozoa in Sistani cattle, and the rest of our library sequences are Eudiplodinium maggii (7\%), Epidinium caudatum (7\%) and Polyplastron multivesiculatum (11\%), Dasytricha (7\%), Uncultured rumen protozoa (7\%). As a result, in our library made, the sequence did not belong to the species of Diploplastron. Previously, the microscopic study of the cilium protozoa in rumen of cattle in Japan showed that Entodiniomorphidae Morphotype was dominant in the rumen, which is consistent with our results (Ito et al., 1994). Dos Rise et al. in 2019, stated that the density and richness (number of genera) of the cilium protozoa in the rumen were strongly influenced by the feeding conditions of the ruminant host. In forage diets, the density is low, and the rich rates of protozoa species are high, while in contrast to concentrate-rich diets, these results are consistent with the results obtained of the present study (Dos Reis et al. 2019).

Kittelmann and Johnson (2011) investigated the population of cilium protozoa in rumen of cattle, sheep, and deer bred in New Zealand using the18S rDNA clone library and PCR-denaturing gradient gel electrophoresis analysis. They showed that the rumen of the cattle (crossbred of Holstein and Jersey) has a population of cilium protozoan dominated by Polyplastron and Ostracodinium. While our study showed Anthodynamuses as the dominant group in the rumen of Sistani cattle, they also stated that the composition of the population of the cilium protozoa in the rumen of the cattle was influenced by the diet, as the composition of the cilium protozoa in the rumen was altered by changing the diet from silage to pasture forage. Meanwhile, deer and sheep had the population of cilium protozoa dominated by Epidinium and Eudiplodinium, and this composition of protozoa was less affected by the diet. Therefore, several factors affect the composition of cilium protozoan species in the rumen of the cattle. Anyway, their findings contradict the findings of this study, which can arise from the type of feed consumed by cattle and the geographical situation of the Sistan region.

In a study, Karnati et al. (2003), microscopic examinations of protozoa in rumen revealed 11 species of protozoan including Entodinium, Diplodinium, Eudiplodinium, Epidinium, Ophryoscolex, Polyplastron, Isotricha, Dasytricha, Ostracodinium, Metadinium, and Enoploplastron. Zhang (2001) also observed 10 species of protozoa including Diplodinium, Isotricha, 
Entodinium, ophryoscolex, Eodinium, Ostracodinium,

Eudiplodinium,

Elytroplaston, Epidinium and

Caloscolex in the sample of rumen fluid of cilium protozoa of two local yellow cows fed with rice straw, (Karnati et al., 2003). But in our research, the library of the rumen fluid revealed the presence of sequences belonging to species of Entodinium, Eudiplodinium, Epidinium, Polyplastron, Dasytricha, and Uncultured rumen protozoa sequences, and in this library, no sequence was not found related to species of Isitricha, Ophryoscolex, Diplodinium.

Gurelli and Uurucuglu (2019) studied on a variety of cilium protozoa in rumen of native cows (B. Taurus Taurus), Antalya, Turkey, with special emphasis on (Entodinium, Ophryscolecidae) Entodiniomorphida, rostradum, and stated that Isotricha prostoma and Entodinium simulans were found to be the most frequent among all species of protozoan in all cows. In their research, they stated that domestic cows in Turkey's Antalya were fed with high-concentrate diets. While phylogenetic analysis of the rumen fluid library in this study did not show the presence of species of Isotricha prostoma and Entodinium simulans in the rumen of Sistani cattle, therefore, the specialization of protozoa in the rumen of different ruminant animals can be due to its strong dependence on host digestive activity or the difference in the geographical condition of the two animals.

Shah et al., in 2016, in research, identified the diversity and relative frequency of protozoa in the rumen of Surti buffalo (Bubalus bubalis) using the sequencing of Shatgan. The taxonomic profiles obtained in comparison with the SILVA SSU database indicated a dominance of species of Litostomatea (99.78\%) and then Coccidia (10.0\%) and Aconoidasida (60.0\%). On the surface of the species of Isotricha, as well as Polyplastron, Dasytricha and
Eudiplodinium dominated. In this study, pathogenic protozoa of species of Coccidia and Aconoidasida including Toxoplasma, Eimeria, and Plasmodium were introduced. The results showed that 77 species and 124 species of protozoa in the enriched sample of protozoa (EPS) found in protozoan enriched sample (EPS) compared to 21 species and 29 species in reference rumen fluid. The species of Entodinium, Epidinium, Polyplastron, Eudiplodinium, Isotrichha, and Dasytricha which were observed in PES, have been previously reported in ruminant animals. Among protosauses, Entodinium $(28.22 \%$ and 5917 sequences) had the highest frequency with Toxoplasma (14.49\% and 3133 sequences) and Epidinium (7.2\% and 1511 sequences).

In another study in 2016 which was made by Gurelli et al., the protozoa of the cilium protozoa in rumen of domestic sheep (Ovis aries) and goat (Capra aegagrus hircus) in Kyrgyzstan were investigated. 12 species, 28 species, and 12 morphotypes were identified in sheep, while 8 species, 12 species, and 4 morphotypes were identified in goat. The frequency of cilium in sheep was $10^{4} \times(28.1 \pm 20)$ and in goats was $37 \times$ $10^{4}$. Dasyriicha ruminantium, Isotricha prostoma, Entodinium simulans, and Ophryoscolex caudatus were the principal species $(100 \%)$ in sheep, and for the first time, the Diplodinium Rangifer was discovered in a domestic sheep. In the Sistani cattle in the Sistan region, the number of cilium protozoan in the rumen was $65.43 \times 10^{4}$. In arid regions, the population of protozoa in the rumen was significantly higher than in moist regions. The reason for this can be arising from the rumen's sustained activity due to the use of forage and increased digestive activity of fiber by bacteria in the rumen of Sistani cattle. The increase in the total number of rumen protozoa in this study is consistent with the results of Frisch and Vercoe (1977) which reported that the 
number of rumen protozoa in Zobu and Brahman (Asian) cows is higher than in European cows. In two different studies on Japanese goats, the number of protozoa was $40.4 \times 104$ (Imai et al., 1978) and $43.9 \times 10^{4}$ (Ito et al., 1994). It has also been reported that the number and species of protozoa vary between different species of ruminants (Wallace and McPherson, 1987).

\section{Rumen Bacteria}

Our findings indicate that the rumen of Sistani cattle have a different spectrum of bacterial species than other ruminants elsewhere in the world. After the incubation period, two criteria for color change (clouding) with ocular observation and $\mathrm{pH}$ reduction of the cultivation medium were used to determine the growth rate of bacteria in each tube. Then, using the MPN table, the number of bacteria per $\mathrm{ml}$ of rumen fluid was estimated at $10^{19} \times 10^{10}$. In this study, 18 clones belonged to the Firmicutes phylum.

Many studies have shown that Bacteroidetes and Firmicutes are the most dominant phylum in the intestinal microbial terrestrial mammals (Singh et al., 2015; Ley et al., 2008; Qin et al., 2010). However, in the present study, Firmicutes was abundant in samples obtained from Sistani cattle of 3.5-5 years old. The effect of age on intestinal bacterial communities has also been reported by Koenig et al, Yatsunenko et al. These studies have reported agerelated changes in human intestinal microbiome (Koeing et al., 2011; Yatesunenko et al., 2012). Han and colleagues also stated in 2015 that the relative frequency of unclassified and uncultured bacteria in goats would decrease with the increasing age.

In a study which was made by Han et al. (2015) on goats of different ages, it has been shown that in 80-day-old goats, Firmicutes (41.01\%), Synergistste $(36.76 \%)$, Bacteroides $(19.70 \%)$ were dominant phylumes was that this demographic distribution procedure changed with increasing the age per 10 days. Finally, at age of 110 days, Bacteroidetes with $63.96 \%$, Firmicutes with $17.92 \%$, Proteobacteria with $8.05 \%$, and Synergists with $7.5 \%$ formed the dominant phylumes in the rumen of goats. In another experiment, using $16 \mathrm{~S}$ rRNA gene sequencing, it was shown that species of Prevotella including 52\% of the total rumen microbiome population, are the most abundant bacteria (Jami and Mizrahi, 2012). The genus Prevotella is the most abundant species among the bacteria available in rumen. Even studies based on cultivation methods have shown that prevotella species make up more than $50 \%$ of all rumen bacteria in goats (Bekel et al., 2010). Pandya et al. (2010) reported that $8.37 \%$ of the clones identified in the rumen of Indian buffaloes belonged to Prevotella ruincola. Also, the presence of Prevotella runnincola in the rumen of Pack and Gayal is also mentioned (Yang et al., 2010). During the experiment, the presence of Prevotella multifornis in the rumen of Sika deer fed with oak leaves (Li et al., 2013). Patel and colleagues (2011) also reported in a study conducted on Surti India's goats. In these animals, fed with a mixture of concentrates and forage, $35 \%$ of the clones belonged to the Bacteroidete phylum and $33.33 \%$ belonged to the Firmicute phylum. It has been shown that only 2 clones from 60 identified clones belong to Prevotella multiformis in the rumen in goats of India (Patel et al., 2011).

It is clear that most digestive system bacteria have not yet been cultured and there are still plenty of uncultured species. Other researchers have also pointed to the presence of these uncultured bacteria in their reports of the rumen in the goats (Han et al., 2015; Patel et al., 2011; Sun et al., 2008). 
Until now, no study has shown except for the study of Han and colleagues in 2015 that bacteria belonging to Synergiststes phylum, as the dominant phylum in the rumen microbiome, can be available. Han and colleagues attained the presence of bacteria from the Synergiststes phylum in the rumen of SBWC (Shaanbei whitecashm) Goats. They stated that Synergistetes could be unique to SBWC goats and could play an important role in digesting the mother's milk in the rumen (Han et al., 2015). Diet is probably the most obvious factor affecting the rumen microbiome (Newbald and Ramos, 2019).

Many of the Botrytis isolates of Butyrivibrio fibrisolvens which are widely observed after feeding different diets are cellulite, but their activity is poor (Watabe et al., 2018).

The bacteria of species of Ruminococcus are one of the major bacteria destructing cellulose in the rumen (Kong et al., 2010; Weimer et al., 1996). Yang et al. (2009) found that the frequency of $R$.flavefaciens is greater than R.albus in the rumen (Yang et al., 2009), which is not consistent with our results, as there is a great deal of discrepancy between their effects that this finding is consumed by the cattle due to the type of diet. As the animals studied feed with roughage. Especially $R$.albus is a positive hot bacteria, fibrolytic and anaerobe, and it seems to be one of the most active cellulolytic bacteria in the rumen which has the ability to reduce cellulose and hemicellulose (Devendran et al., 2016; Kim et al., 2014) .

\section{CONCLUSION}

According to our studies, this study is the first report on the study of the bacterial phylogenetic diversity and rumen protozoa of Sistani cattle in Iran, carried out by cloning, polymerase chain reaction and analyzing the library of $18 \mathrm{~S}$ rRNA and 16S rRNA genes obtained from the rumen fluid contents. Investigating the bacterial sequencing obtained from cattle's rumen also showed that the results obtained are somewhat consistent with the results of other researchers in other countries and in other animals, but in some cases, there are significant differences. However, further studies are needed to investigate the molecular diversity of microorganisms of ruminants rumen in Iran using new generations of sequencing so that a more complete and accurate conception of the microbial ecosystem in the digestive tract of Iranian livestock including bacteria, archaea, fungi and unicellular is acquired. In this study, Entodinium was the dominant protozoa group in the Sistani cattle's rumen. In the library studied, OTUs had a similarity of over $98.50 \%$ with the cilium protozoan sequences identified in the database. The results of the cultivation of bacteria, showed species of Ruminococcus albus, Ruminococcus flavefaciense, Clostridium colinum, Streptococcus equinus and species of butyrivibrio which showed a high similarity of $96.54 \%$ with the bacterial sequences identified in the database. Rumen microbial ecology is too complex. The real scope of this diversity is determined by the use of molecular identification methods for species. The complexity of this diversity is determined by using $16 \mathrm{~S}$ rRNA genes and 18S rRNA genes. Because each microbial species occupies a small area and is found only in some animals.

\section{SUGGESTIONS}

Analysis of the sequence of $18 \mathrm{~S}$ rRNA is not enough to clarify the composition of rumen protozoa. Therefore, in order to analyze the sequence of $18 \mathrm{~S}$ rRNA is required to use localized hybridization and real-time PCR technologies. Data obtained from rDNA sequencing analysis of the small subunit of the ribosome can provide the 
bed to develop other molecular identification techniques such as FISH, FISHFC, DNA microarrays, and quantitative real-time PCR techniques. Using the molecular techniques of the new generation can reveal a huge wealth of microbial diversity and new species in the rumen. Metagenomics and metatranscriptomics symmetric data can also extend our knowledge of the diversity of the rumen microbial phylogenetic through determining the sequence of the genome of the new microorganisms.

\section{REFERENCES}

ALEMU, B.; GARI, G.; LIBEAU, G.; KWIATEK, O.; KIDANE, M., et al. Molecular detection and phylogenetic analysis of Peste des petits ruminants virus circulating in small ruminants in eastern Amhara region, Ethiopia. BMC veterinary research, v.15, n.1, 84, 2019.

BEKELE, A. Z.; KOIKE, S.; KOBAYASHI, Y. (2010). Genetic diversity and diet specificity of ruminal Prevotella revealed by $16 S$ rRNA genebased analysis. FEMS microbiology letters, v.305, n. 1, p. 49-57, 2010.

CERON CUCCHI, M.; MARCOPPIDO, G.; MORICI, G.; et al. Ciliate protozoa of the forestomach of llamas (Lama glama) from locations at different altitude in Argentina. Zootaxa, v.4067, n.1, p. 4956, 2016.

DAS, K. C.; QIN, W. Isolation and characterization of superior rumen bacteria of cattle (Bos taurus) and potential application in animal feedstuff. Open Journal of Animal Sciences, v. 2, n. 4, p. 224, 2012.

DEHORITY, B. A. Evaluation of subsampling and fixation procedures used for counting rumen protozoa. Applied and Environmental
Microbiology, v. 48, n.1, p. 182-185, 1984.

DEHORITY, B. A. Laboratory manual for classification and morphology of rumen ciliate protozoa. CRC Press, 2018.

DEVENDRAN, S.; ABDEL-HAMID, A. M.; EVANS, A. F.; et al. Multiple cellobiohydrolases and cellobiose phosphorylases cooperate in the ruminal bacterium Ruminococcus albus 8 to degradecellooligosaccharides.

Scientific Reports, v. 6, p.353-362, 2016.

DOS REIS, C. C.; MAEDA, E. M.; CEDROLA, F.; et al. Diet and breed alter community structures of rumen protozoa in cattle subjected to different feeding systems. Semina: Ciências Agrárias, v.40, n.2, 909-918, 2019.

FARAJI-AROUGH, H.; ROKOUEI, M.; MAGHSOUDI, A.; et al. Effect of Using Reproductive Technologies on Genetic Progress in Sistani Native Cattle of Iran: A Simulation Study. Iranian Journal of Applied Animal Science, v. 9. n.1. 2019.

FRISCH, J. E.; VERCOE, J. E. Food intake, eating rate, weight gains, metabolic rate and efficiency of feed utilization in Bos taurus and Bos indicus crossbred cattle. Animal Science, v. 25, n.3, p. 343-358, 1977.

GHARECHAHI, J.; ZAHIRI, H. S.; NOGHABI, K. A.; et al. In-depth diversity analysis of the bacterial community resident in the camel rumen. Systematic and Applied Microbiology, v. 38, n. 1, p. $67-76,2015$.

GORJI, Z. E.; KHALEDI, K. J.; AMOLI, A. D.; GANJIBAKHSH, M.; et al. Establishment and characteristics of Iranian Sistani cattle fibroblast bank: a way to genetic conservation. Conservation Genetics Resources, v.9, n. 2, p. 305-312, 2017.

GÜRELLI, G.; YÜRÜCÜOĞLU, N. Ruminal ciliate diversity of domestic 
cattle in Anta-lya, Turkey, with special emphasis on morphology of Entodinium rostratum (Entodiniomorphida, Ophryoscolecidae). Protistology, v.13, n.2, p.71-78, 2019.

GÜRELLI, G.; CANBULAT, S.; ALDAYAROV, N.; et al (2016). Rumen ciliate protozoa of domestic sheep (Ovis aries) and goat (Capra aegagrus hircus) in Kyrgyzstan. FEMS microbiology letters, v. 363, n. 6, 2016.

HAN, X.; YANG, Y.; YAN, $\mathrm{H}$. ; et al. Rumen bacterial diversity of 80 to 110 day-old goats using 16S rRNA sequencing. PloS one, v.10, n. 2, 2015.

HANAFY, R. A.; ELSHAHED, M. S.; LIGGENSTOFFER, A. $S$.; et al. Pecoramyces ruminantium, gen. nov., sp. nov., an anaerobic gut fungus from the feces of cattle and sheep. Mycologia, v. 109, n. 2, p. 231-243, 2017.

HERNÁNDEZ-MARTÍNEZ, D.; REYESBATLLE, M.; CASTELAN-RAMÍREZ, I.; et al. Evaluation of the sensitivity to chlorhexidine, voriconazole and itraconazole of T4 genotype Acanthamoeba isolated from Mexico. Exp parasitol, v.197, p.29-35, 2019.

IMAI, S.; KATSUNO, M.; AND OGIMOTO, K. Distribution of rumen ciliate protozoa in cattle, sheep and goat and experimental transfaunation of them. Japanese Journal of Zootechnical Science, v. 49, p. 494505, 1978.

ITO, A.; IMAI, S.; OGIMOTO, K. (1994). Rumen ciliate composition and diversity of Japanese beef black cattle in comparison with those of HolsteinFriesian cattle. Journal of Veterinary Medical Science, v. 56 , n.4, p. 707714, 1994.

JAMI, E.; MIZRAHI, I. Composition and similarity of bovine rumen microbiota across individual animals. Plos one, 7(3), e33306, 2012.
KARNATI, S. K. R.; YU, Z.; SYLVESTER, J. T.; et al. Specific PCR amplification of protozoal 18S rDNA sequences from DNA extracted from ruminal samples of cows. Journal of Animal Science, v. 81, n.3, p. 812-815, 2015.

KIM, J. N.; HENRIKSEN, E. D.; CANN, I. $\mathrm{K}$, et al. Nitrogen utilization and metabolism in Ruminococcus albus 8 . Appl. Environ Microbiol, v. 80, n.10, p. 3095-3102, 2014.

KIM, M., PARK, T., \& YU, Z. Metagenomic investigation of gastrointestinal microbiome in cattle. Asian-Australasian Journal of Animal Sciences, v.30, n.11, p. 1515, 2017.

KITTELMANN, S.; JANSSEN, P. $\mathrm{H}$. Characterization of rumen ciliate community composition in domestic sheep, deer, and cattle, feeding on varying diets, by means of PCR-DGGE and clone libraries. FEMS Microbiology Ecology, v.75, n.3, p.468-481, 2011.

KITTELMANN, S.; DEVENTE, S. R.; KIRK, M. R.; et al. Phylogeny of intestinal ciliates, including Charonina ventriculi, and comparison of microscopy and $18 \mathrm{~S}$ rRNA gene pyrosequencing for rumen ciliate community structure analysis. Applied and Environmental Microbiology,v. 81, n. 7, p. 2433-2444, 2015.

KLINDWORTH, A.; PRUESSE, E.; SCHWEER, T.; Evaluation of general $16 S$ ribosomal RNA gene PCR primers for classical and next-generation sequencing-based diversity studies. Nucleic Acids Research, v. 41, n.1, e1e1, 2013.

KOENIG, J. E.; SPOR, A.; SCALFONE, N.; FRICKER, A. D.; et al. Succession of microbial consortia in the developing infant gut microbiome. Proceedings of the National Academy of Sciences, 108 (Supplement 1), 4578-4585, 2011. 
KONG, Y.; TEATHER, R.; FORSTER, R. Composition, spatial distribution, and diversity of the bacterial communities in the rumen of cows fed different forages. FEMS Microbiology ecology, v. 74, n.3, p. 612-622, 2010.

KRAUSE, D. O.; DENMAN, S. E.; MACKIE, R. I.; et al. Opportunities to improve fiber degradation in the rumen: microbiology, ecology, and genomics. FEMS Microbiology Reviews, v.27, n.5, p. 663-693, 2003.

KRAUSE, D. O.; NAGARAJA, T. G.; WRIGHT, A. D. G.; Board-invited review: Rumen microbiology: Leading the way in microbial ecology. Journal of Animal science, v. 91, n.1, p. 331-341, 2013.

KUMAR, R.; SARKHEL, S. P.; KUMAR, S.; et al. Molecular characterization and phylogenetic analysis of Trypanosoma evansi from Northern India based on 18S ribosomal gene. Veterinary Parasitology: Regional Studies and Reports, 15, 100259, 2019.

LENG, J.; ZHONG, X.; ZHU, R. J.; et al. Assessment of protozoa in Yunnan Yellow cattle rumen based on the $18 \mathrm{~S}$ rRNA sequences. Molecular Biology Reports, v. 38, n.1, p.577-585, 2011.

LEY, R. E.; LOZUPONE, C. A.; HAMADY, M.; et al. Worlds within worlds: evolution of the vertebrate gut microbiota. Nature Reviews Microbiology, v. 6, n.10, 776, 2008.

LI, Z. P.; LIU, H. L.; LI, G. Y.; et al. Molecular diversity of rumen bacterial communities from tannin-rich and fiberrich forage fed domestic Sika deer (Cervus nippon) in China. BMC Microbiology, v.13, n.1, 151, 2013.

LI, Z.; DENG, Q.; LIU, Y.; et al. Dynamics of methanogenesis, ruminal fermentation and fiber digestibility in ruminants following elimination of protozoa: a meta-analysis. Journal of Animal Science and Biotechnology, 9(1), 89.
NAGARAJA, T. G. Microbiology of the rumen. In: Rumenology (pp. 39-61). Springer, Cham, 2016.

NEWBOLD, C. J.; RAMOS-MORALES, E. (2019). Microbiome of the rumen, 2019.

PANDYA, P. R.; SINGH, K. M.; PARNERKAR, S.; TRIPATHI, A. K.; MEHTA, H. H., et al. Bacterial diversity in the rumen of Indian Surti buffalo (Bubalus bubalis), assessed by $16 \mathrm{~S}$ rDNA analysis. Journal of Applied Genetics, v. 51, n.3, p. 395-402, 2010.

PATEL, J. K. M.; JHALA, M. K.; SONI, P., SHABIR, N.; Molecular characterization and diversity of rumen bacterial flora in Indian goat by $16 S$ rDNA sequencing. Online Vet Journal, v. 6, n. $6,2011$.

QI, M.; JAKOBER, K. D.; MCALLISTER, T. A.; et al. Rumen microbiology. Animal and plant productivity. Encyclopedia of Life Support Systems. EOLSS, Oxford, 161-176, 2010.

QIN, J.; LI, R.; RAES, J.; et al. A human gut microbial gene catalogue established by metagenomic sequencing. Nature, v.464, n. 7285,59 , 2010.

RINGO, A. E.; MOUMOUNI, P. F. A.; TAIOE, M.; et al (2018). Molecular analysis of tick-borne protozoan and rickettsial pathogens in small ruminants from two South African provinces. Parasitology international, v.67, n.2, p. 144-149, 2018.

ROEHE, R.; DEWHURST, R. J.; DUTHIE, C. A., ROOKE, J. A.; Bovine host genetic variation influences rumen microbial methane production with best selection criterion for low methane emitting and efficiently feed converting hosts based on metagenomic gene abundance. PLoS genetics, 12(2), e1005846, 2016.

SHAH, R. K.; PATEL, A. K.; SHAH, T. $\mathrm{M}$;; et al. Analysis of community 
structure and species richness of protozoa enriched rumen metagenome from Indian Surti by shotgun sequencing. Current Science, v.111, n. 1, p.184, 2016.

SINGH, K. M.; JISHA, T. K.; REDDY, B., PARMAR, N.; et al. Microbial profiles of liquid and solid fraction associated biomaterial in buffalo rumen fed green and dry roughage diets by tagged $16 \mathrm{~S}$ rRNA gene pyrosequencing. Molecular Biology Reports, v. 42, n.1, p. 95-103, 2015.

SUN, Y. Z.; MAO, S. Y.; YAO, W.; et al. DGGE and 16S rDNA analysis reveals a highly diverse and rapidly colonising bacterial community on different substrates in the rumen of goats. Animal, v.2, n.3, 391-398, 2008.

WALLACE, R. J.; MCPHERSON, C. A. Factors affecting the rate of breakdown of bacterial protein in rumen fluid. British Journal of Nutrition, v. 58, n.2, p. 313323, 1987.

WANG, S.; GILLER, K.; et al. Contribution of Ruminal Fungi, Archaea, Protozoa, and Bacteria to the Methane Suppression Caused by Oilseed Supplemented Diets. Frontiers in Microbiology, v. 8, p.1864, 2017.

WEIMER, P. J. Ruminal cellulolytic bacteria: physiology, ecology and beyond. In: USDA-ARS Proceedings of the Dairy Forage Research Center
Conference with the Dairy and Forage Industries, 1996.

WRIGHT, E. S.; BAUM, D. A. Exclusivity offers a sound yet practical species criterion for bacteria despite abundant gene flow. BMC Genomics, v.19, n.1, 724, 2018.

YANG, L. Y.; CHEN, J.; CHENG, X. L.; et al. Phylogenetic analysis of 16S rRNA gene sequences reveals rumen bacterial diversity in Yaks (Bos grunniens). Molecular Biology Reports, v. 37, n.1, p. 553-562, 2010.

YANG, S. L.; BU, D. P.; WANG, J. Q.; et al. Soybean oil and linseed oil supplementation affect profiles of ruminal microorganisms in dairy cows. Animal, v. 3, n.11, p. 1562-1569, 2009.

YATSUNENKO, T.; REY, F. E.; MANARY, M. J.; et al. (2012). Human gut microbiome viewed across age and geography. Nature, v.486, n.7402, p. 222, 2012. 